leukaemia, ${ }^{1516}$ and, with young patients surviving previously lethal conditions, the problem can only increase.

${ }^{1}$ Fox, H, and Langley, F A, Tumours of the Ovary, p 210. London, Heinemann, 1976.

2 Proskauer, G G, American fournal of Obstetrics and Gynecology, 1946, 52,845 .

${ }^{3}$ Malkasian, G D Jun, Symmonds, R E, and Dockerty, M B, Obstetrics and Gynecology, 1965, 25, 810.

4 Feldman, H J, and Postoloff, A V, fournal of International College of Surgeons, 1964, 41, 371.

5 London, J L, and Kazmers, N, International Surgery, 1966, 46, 142.

6 Breen, J L, and Neubecker, R D, Obstetrics and Gynecology, 1963, 21, 669.

7 Breen, J L, and Neubecker, R D, Annals of the New York Academy of Sciences, 1967, 142, 658.

8 Thurlbeck, W M, and Scully, R E, Cancer, 1960, 13, 804.

9 Wisniewski, M, and Deppisch, W M, Cancer, 1973, 32, 440.

${ }^{10}$ Benirschke, K, Easterday, C, and Abramson, D, Obstetrics and Gynecology, $1960,15,512$.

11 Murray, R C, and Hofmeister, F J, Obstetrics and Gynecology, 1961, 18, 474.

${ }^{12}$ Malkasian, G D, and Symmonds, R E, American fournal of Obstetrics and Gynecology, 1971, 110, 1020.

13 Curry, S L, Smith, J P, and Gallagher, H S, American fournal of Obstetrics and Gynecology, 1978, 131, 845.

14 Smith, J P, and Rutledge, F, American fournal of Obstetrics and Gynecology, 1976, 107, 691 .

15 Lancet, 1977, 1, 1041

16 Holmes, G E, and Holmes, F F, Cancer, 1978, 41, 1317.

\section{Legislation and animal research: is reform due?}

The Cruelty to Animals Act $(1876)^{1}$ has passed its centenary unamended. This is no mean achievement for an Act which affects many more biomedical scientists today than it did even 30 years ago, and pays credit equally to those who drafted its provisions and those who have since been concerned with its administration. When its provisions were discussed at the Universities Federation for Animal Welfare Symposium in $1976^{2}$ most British biomedical research workers (while recognising that the Act was not perfect) preferred to opt for the known system of control rather than any untried version. Nevertheless, in the control of the use of animals by scientists there are several grey areas that have to be covered by stretching the interpretation of the Act, causing concern both to some of those working in the field and to many outside observers. These problems have arisen not only through recent developments in biomedical research but also because of the vast increase in statutory requirements for testing the safety and potency of pharmaceutical and other products. Minor procedures, to take one example, may or may not be subject to control by the Home Office according to whether the objective is deemed to be "experimental" or not; but there is often little difference to the animal. Indeed the definition of an experiment as expressed in the 1876 Act-" "a procedure seeking new knowledge on a living vertebrate animal calculated to cause pain"could not envisage the extent of the changes which have taken place since.

Today over half the experiments reported each year are carried out in commercial laboratories. ${ }^{3}$ Paradoxically, the Department of Health, which stipulates the need for so many of the tests in the name of public safety, is not the Government department under whose jurisdiction the animal tests are controlled, and hence comment by the public and the media is often misdirected. Certainly it seems that closer links could be established between the department and the Home Office. Alternatively, the statutory tests could be excluded from any legislation governing the more basic forms of animal research, but other administrative difficulties might then be introduced.

An expert committee assembled by the Council of Europe held two meetings in 1978 to draw up a convention to protect animals used in research and testing from unlicensed exploitation. If possible, agreement will be reached among the 21 European member states on minimum standards for conditions under which animals are bred, bought, and used in experiments or tests; and the council has taken on the responsibility for producing a rational document on this emotive subject. Some proposals were introduced in the Consultative Assembly of the Council of Europe in 1971,4 and if accepted in their original form these would have greatly inhibited research in medical and veterinary science. This threat now seems to have receded. Britain will probably become a signatory to the new convention when it is completed-indeed, it speaks well for the British system of control that the early drafts embody most of the principles already practised here. Though there may be several new requirements, some are familiar, having been included in the recommendations of the Littlewood Report in 1965. ${ }^{5}$ Some have been gradually put into practice already even though not formally incorporated into the legal regulations. In some aspects the British system is more stringent than those applied elsewhere, but little change seems likely in these areas. On balance licence holders under the Cruelty to Animals Act will probably accept an updating and revision of its provisions-provided that there is adequate consultation. The climate of opinion favours review - and it will also provide an opportunity for informing the public of the need for animal research. These chances should not be lost if Britain is to continue to lead opinion in matters of ethics and the rights and welfare of animals.

British scientists are, however, divided on whether to defer any necessary amendments until after publication of the Council of Europe convention, which may be in two or three years' time, or to proceed independently to rewrite the 1876 Act. The second course would preserve the best from the existing system while at the same time anticipating the slightly wider requirements of the European consensus. Whichever route is chosen, the result should be a clearer statement of the law, strengthened on aspects of animal welfare, more reassuring to the lay public that adequate control is exercised and seen to be practised, and at the same time allowing knowledge of disease and its control to advance. Implementing such reforms will not be helped, however, by making them the subject of party politics ${ }^{6}$ - nor by the noisy, unrealistic claims made by some pressure groups. Fortunately, Smyth's recent book on Alternatives to Animal Experiments ${ }^{7}$ has provided a balanced view, recommending further scientific appraisal by investigation of the validity of testing for toxicity in tissue culture and of the use of immunoassay techniques. Nevertheless, such replacement methods have only a limited application and their further development must inevitably also use some animals.

The Research Defence Society has recently discussed possible measures for reform and would probably recommend for inclusion in any new Bill a more practical and simpler method of application for a licence, inspection of all animals on registered premises whether on experiment or not, registration of animal breeders and suppliers, and a requirement to have a veterinary service as appropriate to the size and type of establishment concerned. Registration of premises, licensing of scientists, annual reporting for statistical purposes, and an advisory committee would, of course, remain basic components of any Bill. Any revised Act is unlikely to retain the words "cruelty to animals" in its title, since its purpose will be seen 
to be the protection of animals in laboratories rather than the regulation of experiments. Furthermore, the scope of the word experiment is likely to extend beyond its historic limits; and inevitably future annual returns will then show more "experiments." This change should be welcomed, for inclusive figures are preferable to apparently reassuring ones which do not represent all the facts.

${ }_{1}$ Cruelty to Animals Act 1876. London, HMSO, 1876.

2 Universities Federation for Animal Welfare, Symposium Proceedings. The Welfare of Laboratory Animals-Legal, Scientific, and Humane Requirements. Potters Bar, UFAW.

${ }^{3}$ Home Office, Experiments on Living Animals-Statistics-1977. London, HMSO, 1978.

4 Recommendation 621, Consultative Assembly of the Council of Europe. London, HMSO, 1971.

5 Report of the Departmental Committee on Experiments on Animals. London, HMSO, 1965.

6 The Labour Party, Living Without Cruelty, Labour's Charter for Animal Protection. London, Labour Party, 1978.

7 Smyth, D H, Alternatives to Animal Experiments. London, Scolar Press, 1978.

\section{Tumour markers in breast cancer}

Tumour markers are already used in the routine management of some types of cancer. Measuring the serum acid phosphatase concentration aids the diagnosis of prostatic carcinoma, and estimating monoclonal globulin is valuable both in diagnosis and in monitoring treatment in patients with myeloma. More sensitive markers, such as calcitonin in thyroid medullary carcinoma and human chorionic gonadotrophin (HCG) in choriocarcinoma, can be used to identify a tumour before it becomes detectable by other means. ${ }^{12}$

As yet, however, no effective diagnostic marker has been found for primary breast cancer; none tested has both the sensitivity and the specificity required. Even so, less sensitive markers would be of clinical value in metastatic disease, firstly, in selecting patients for additional treatment after mastectomy and, secondly, in the early identification of the failure or success of treatment. Patients might then be spared inappropriate or ineffective treatment, and new regimens could be evaluated more rapidly and with greater accuracy.

While there is no ideal single marker for breast cancer, many patients do have raised urinary or serum concentrations of various substances which appear to be related to tumour stage. This presents the possibility of using a combination of markers, either in a multivariate analysis or as a screening procedure to pick out the best marker for follow-up in that patient. The putative markers most frequently studied are milk proteins (casein ${ }^{3}$ or lactalbumin ${ }^{4}$ ); known products of other tumours (carcinoembryonic antigen (CEA), human chorionic gonadotrophin (HCG), or calcitonin); acute-phase proteins (haptoglobin or C-reactive protein); and serum enzymes (such as alkaline phosphatase).

Tormey et $a l^{5}$ measured CEA, HCG, and a nucleoside: they found one or more of these abnormal in $97 \%$ of patients with advanced disease and in $67 \%$ of patients with diseased nodes after mastectomy. Franchimont et $a l^{6}$ described one or more abnormalities in $69 \%$ of patients with local and in $89 \%$ of those with advanced disease on the basis of serum assays for CEA, casein, HCG, and HCG $\beta$. The measurement of 19 markers, including acute-phase proteins and possible tumour products, turned up abnormalities in all 17 patients with metastatic disease but in only two of nine patients with local breast cancer. $^{7}$

Though impressive, these cumulative abnormalities should be interpreted with caution for several reasons. Firstly, the more substances measured the more false-positive results will occur, unless the normal ranges are expanded. Secondly, even in advanced disease, many of the abnormalities are only just above the normal range, suggesting that they are unlikely to be sensitive guides to the amount of tumour. Thirdly, the abnormalities reported with some of the markers vary greatly among authors and even among different publications from the same authors. These apparent discrepancies cannot be explained by differences in the patients studied and are in part due to assay differences. For example, a raised serum calcitonin concentration was reported in all of eight patients studied by one group, ${ }^{8}$ but later the same authors reported raised values in only two of 17 patients. ${ }^{7}$ Abnormal casein concentrations were described in $80 \%$ of patients with metastatic disease ${ }^{3}$ but later in only $44 \%$, despite a reported increase in assay sensitivity. Others have found raised casein concentrations in only $19 \%$ of the patients studied ${ }^{9}$ or even no more often than in controls. ${ }^{10}$ The fourth factor is that the value of studying acute-phase proteins is likely to be limited because they can be affected by treatment which alters the host's immune responsiveness, irrespective of the effects on the amount of tumour. Biochemical changes within the normal range ${ }^{11}$ are difficult to interpret unless the physiological variation is known.

The results of CEA assays have proved more consistent among authors, but finding a marker that is commonly abnormal is only the first step in defining its clinical value. Well-designed longitudinal studies showing that marker concentrations alter appropriately in relation to progression or regression of tumour have been reported only for $\mathrm{CEA}^{12}$ and HCG. ${ }^{13}$ There are no satisfactory reports of serial measurements after mastectomy to determine the "lead-in time" (the period by which a marker abnormality precedes clinical evidence of recurrence).

We have too little information about any of the tumour markers to justify their use in determining treatment at any stage. Possibly in advanced metastatic disease the effects of treatment could be monitored more precisely by a combination of markers, but as treatment is mainly palliative their use would be unlikely to result in any direct improvement in morbidity or mortality. In local breast cancer we need new and more sensitive tumour markers-probably tumour products-if we are to identify patients with minimal residual disease accurately. Nevertheless the present markers may help to identify patients with a higher probability of having residual disease ${ }^{13}$ than those selected by the degree of lymph node disease alone.

\footnotetext{
${ }^{1}$ Melvin, $\mathrm{K} \mathrm{E} \mathrm{W,} \mathrm{Tashjian,} \mathrm{A} \mathrm{H,} \mathrm{and} \mathrm{Miller,} \mathrm{H} \mathrm{H,} \mathrm{Recent} \mathrm{Progress} \mathrm{in}$ Hormone Research, 1972, 28, 399

2 Bagshawe, K D, et al, fournal of Obstetrics and Gynaecology of the British Commonwealth, 1973, 80, 461.

${ }^{3}$ Hendrick, J C, and Franchimont, P, European fournal of Cancer, 1974, 10 , 725

4 Woods, K L, et al, European fournal of Cancer, in press.

5 Tormey, D C, et al, Cancer, 1975, 35, 1095.

${ }^{6}$ Franchimont, $\mathrm{P}$, et al, in Cancer Related Antigens, ed P Franchimont, p 203. Amsterdam, North Holland, 1976

7 Coombes, R C, et al, Lancet, 1977, 1, 132.

${ }^{8}$ Coombes, R C, et al, Lancet, 1974, 1, 1080.

${ }^{9}$ Cowen, D M, et al, European fournal of Cancer, 1978, 14, 885.

${ }_{11}$ Monaco, M E, et al, Cancer Research, 1977, 37, 749.
Anderson, J M, Stimson, W H, and Kelly, F, British fournal of Surgery, $1976,63,819$.

12 Tormey, D C, et al, Cancer, 1977, 39, 2397.

13 Tormey, D C, et al, Cancer, 1977, 39, 2391.
} 